RFP-2837

May 14, 1979
Wh. 2657

RFP-2837

May 14,1979

\title{
CARBIDE PRECIPITATION IN THE HEAT AFFECTED ZONE OF A \\ GTA WELD IN 21-6-9 STAINLESS STEEL
}

M. J. Carr

W. G. Thorvaldson

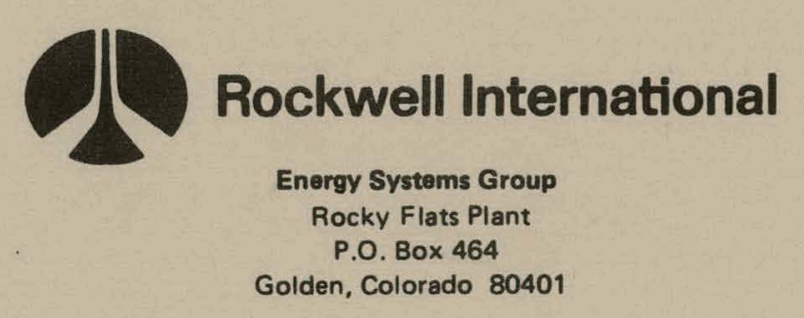

U. S. DEPARTMENT OF ENERGY

CONTRACT DE-AC04-76DPO3533 


\section{DISCLAIMER}

This report was prepared as an account of work sponsored by an agency of the United States Government. Neither the United States Government nor any agency Thereof, nor any of their employees, makes any warranty, express or implied, or assumes any legal liability or responsibility for the accuracy, completeness, or usefulness of any information, apparatus, product, or process disclosed, or represents that its use would not infringe privately owned rights. Reference herein to any specific commercial product, process, or service by trade name, trademark, manufacturer, or otherwise does not necessarily constitute or imply its endorsement, recommendation, or favoring by the United States Government or any agency thereof. The views and opinions of authors expressed herein do not necessarily state or reflect those of the United States Government or any agency thereof. 


\section{DISCLAIMER}

Portions of this document may be illegible in electronic image products. Images are produced from the best available original document. 


\section{LEGAL NOTICE}

This report was prepared as an account of work sponsored by the United States Government. Neither the United States nor the Department of Energy, nor any of their employees, nor any of their contractors, subcontractors, or their employecs, makes any warranty, expressed or implied, or assumes any legal liability or responsibility for the accuracy, completenesss or usefulness of any information, apparatus, product or process disclosed, or represents that its use would not infringe privately owned rights.

Printed in the United States of America

Available from the

National Technical Information Service

U. S. Department of Commerce

Springfield, Virginia 22161

Price. Printed Copy $\$ 4.50$ Micrufiche $\$ 3.00$

Price Is Subject to Change Without Notice 
Printed

May 14, 1979
RFP-2837

UC-25 MATERIALS

TID-4500-R66

\title{
CARBIDE PRECIPITATION IN THE HEAT AFFECTED ZONE OF A GTA WELD IN 21-6-9 STAINLESS STEEL
}

\author{
M. J. Carr
}

W. G. Thorvaldson

\section{ROCKWELL INTERNATIONAL ENERGY SYSTEMS GROUP ROCKY FLATS PLANT : \\ P.O. BOX 464 GOLDEN, COLORADO 80401}

This report was prepared as an account of work sponsored by the United States Covernment Nerher United States nor the United States Deparher the Energy, not any of their employees, nor any of their contractors, subcontractors, or their employees, makes any warranty, express or implied, or assumes any legal liability or responsibulity for the accuracy cos any legal or usefulness of any information, apparatus, product or process disclosed. Or represents that is life would not infringe privately owned rights.

Prepared under Contract DE-AC04-76DPO3533 for the

Albuquerque Operations Office

U.S. Department of Energy 
RFP-2837 


\section{CONTENTS}

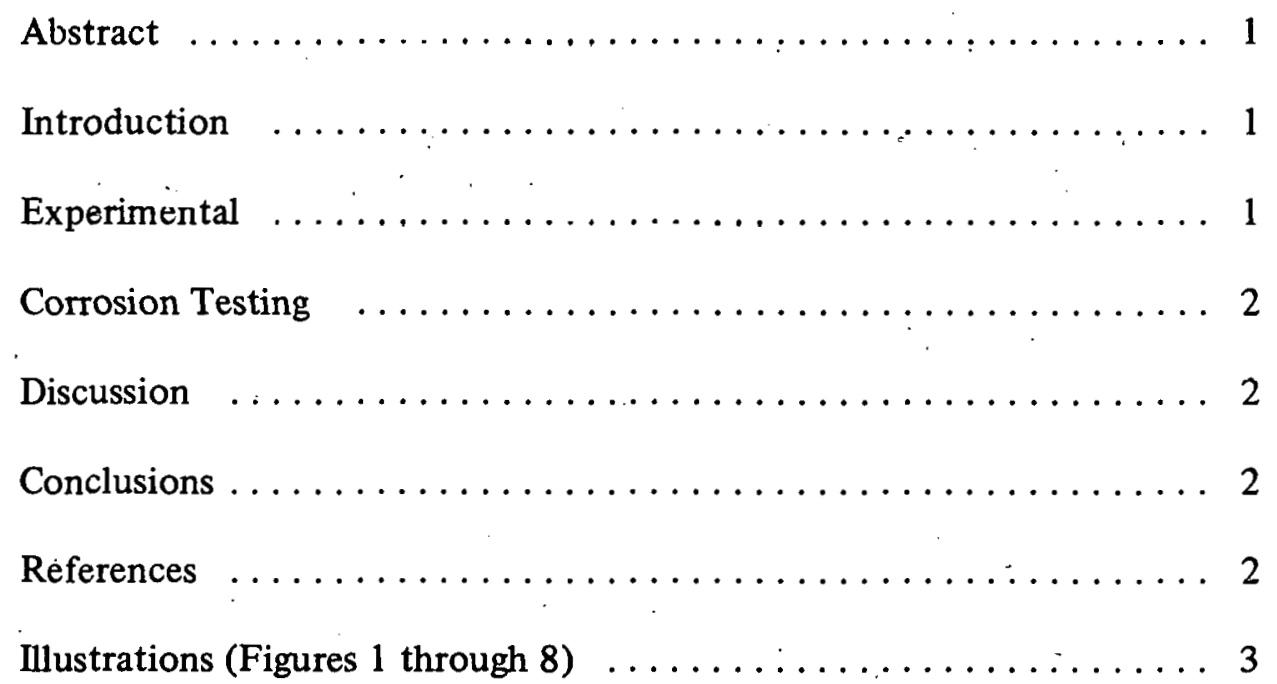


RFP-2837

ACKN OWLEDGMENT

The authors wish to thank J. F. Capes for skillfully preparing specimens for optical metallogruphic exduniualiun. 
RFP-2837

\title{
CARBIDE PRECIPITATION IN THE HEAT AFFECTED ZONE OF A
}

\section{GTA WELD · IN 21-6-9 STAINLESS STEEL}

\author{
M. J. Carr and W. G. Thorvaldson
}

\begin{abstract}
Grain boundary precipitation was observed in a multipass GTA weld in 21-6-9 stainless steel. The precipitate was identified by electron diffraction as $\mathrm{M}_{23} \mathrm{C}_{6}$-type carbide. The presence of these carbide particles did not cause intergranular attack in standard corrosion tests.
\end{abstract}

\section{INTRODUCTION}

During development work on multipass TIG (GTA) welds in 21-6-9 stainless steel, optical metallographic analysis showed the presence of grain boundary precipitates in the heat affected zone (HAZ) near the root of the weld. Because grain boundary precipitation in stainless steels can increase susceptibility to intergranular attack, an attempt was made to identify the precipitates and to determine what effect the precipitation had on the corrosion properties of this material. It is the purpose of this report to describe the results obtained in that study, which showed that the precipitate was $\mathrm{M}_{23} \mathrm{C}_{6}$-type carbide (or carbonitride) but that these precipitates did not cause intergranular failure in standard corrosion tests.

\section{EXPERIMENTAL}

The work described in this report was done on a 5-pass GTA weld in 21-6-9 austenitic stainless steel. Figure 1 shows a cross section of the weld. Grain boundary precipitation was observed in the heat affected zone adjacent to the first pass at the root of the weld. Figure 2 shows the heat affected zone near the root pass. Significant grain growth has occurred and the grain boundaries are decorated with fine precipitates. Figure 3 is an optical micrograph of the unaffected base metal beyond the
HAZ showing the typical grain size and cleanliness of this steel. When this weld was subjected to the ASTM oxalic etch test (ASTM-273A), the area of the heat affected zone which had showed grain boundary precipitation exhibited a "ditch" structure, ${ }^{1}$ indicating possible sensitization; whereas other areas in the upper portions of the heat affected zone and in the base metal showed "step" structures, indicating that they were not sensitized. Figure 4 is an optical micrograph showing the structure of the heat affected zone in area "A" in Figure 1, after the oxalic etch test. The lower portion shows the ditch structure while the upper portion-shows the step structure. The transition is quite sharp and is due to the temperature cycles caused by successive weld passes. Only the weld root pass area showed grain boundary precipitation.

Because the grain boundary precipitates.were very small, they could not be identified optically, so specimens of the heat affected zone near the root pass of the weld (area " $B$ " in Figure 1) were thinned and examined in a Philips EM200 transmission electron microscope.

Figure 5 is an electron micrograph showing typical grain boundary particles in the heat affected zone. These particles were about $0.1 \mu$ in length and were found only at grain boundaries and incoherent twin boundaries, and not at coherent twin boundaries or throughout the matrix. Selected area electron diffraction patterns were obtained which showed that these particles were $\mathrm{M}_{23} \mathrm{C}_{6}$-type carbides (FCC, $\mathrm{a}_{\mathrm{O}}=10.6 \AA$ ). It is possible that the particles, which have the crystal structure of $\mathrm{M}_{23} \mathrm{C}_{6}$, may in fact, contain nitrogen substituting for some carbon and then would be called a carbonitride. P. Landon at Lawrence Livermore Laboratory has expressed 
this view and has been doing research on this point. However, the findings presented here do not address that question and the particles are assumed to be carbides. Figure 6 is an electron diffraction pattern from the area of Figure 5 and shows the pattern of the $11 \overline{4}$ zone of $\mathrm{M}_{23} \mathrm{C}_{6}$. The indicated pair of spots were imaged in the darkfield mode (Figure 7) to confirm that these particles were the source of the pattern. No simple orientation relationship between the carbide particle and either adjacent grain was found.

\section{CORROSION TESTING}

In order to test the effect of the observed precipitation on the corrosion properties of this material, sections of the weld were subject to two, standard, corrosion tests. One sample was subjected to the Huey test, which involves exposing the sample to boiling nitric acid for five days and recording weight loss at 24 hour intervals. No significant weight loss was observed $(0.002 \mathrm{~g} / 48$ hr., max.), which is not surprising in view of the small volume fraction of sensitized metal. However, subsequent metallographic observation of the sensitized area (Figure 8) showed only slight grain boundary etching as the result of this test, and no gross intergranular attack. Resistance to corrosion under these conditions indicates that although precipitation has occurred, only limited areas in the grain boundaries have been affected and a continuous or interconnected sensitized zone has not formed. The low carbon content of this steel limits the amount of carbide which can form, and usually no carbide precipitation is observed.

A second sample was subjected to the Modified Strauss Test which involves exposing the sample to an $\mathrm{H}_{2} \mathrm{SO}_{4}-\mathrm{CuSO}_{4}$ solution for 72 hours then bending the specimen to open cracks. This test exposes the sample to a different corrosion potential from that in the Huey Test and, while it is usually considered to be a milder test, it occasionally produces attack in materials which are not affected by the Huey solution. ${ }^{2}$ :The results of this test were also negative, with no cracking being observed after bending.

\section{DISCUSSION}

Precipitation as the result of welding has not previously been reported in 21-6-9 stainless steel. Carbide precipitation has been observed in forging made from 21-6-9. ( $\mathrm{Fe}, \mathrm{Cr}$ ) sigma phase has been formed in 21-6-9 by aging cold worked sheet 20 hours at $1350^{\circ} \mathrm{F}^{3}$ Apparently the temperature cycles as the result of welding are inadequate to cause precipitation in most cases. However, the repeated thermal cycling, possibly in combination with the stresses associated with the multiple weld passes, appears to be sufficient to cause precipitation in the heat affectcd zone near the root pass. The extent of precipitation was small and did not significantly sensitize the material to the two corrosive environments used in this study.

\section{CONCLUSIONS}

1. Thermal cycles experienced during welding can cause the formation of $\mathrm{M}_{23} \mathrm{C}_{6}$-type carbide (or carbonitride) in the heat affected zone in 21-6-9 stainless steel welds.

2. Since the carbide was observed only near the root pass and not in succeeding passes, modifications of the welding procedurc (number of passes, heat sinks) may be possible which eliminate carbide formation.

3. The amount of precipitation was small and did not seriously degrade the performance of this alloy in either the Hucy Test of the Modified Strauss Test.

\section{REFERENCES}

1. ASTM Standards 1973, No. 262.

2. F. G. Wilson, Brit. Corr. Jour., 6, 1971, p. 100.

3. V. K. Grotzky, private communication, Rockwell International. 


\section{L L U S T R A T I O N S}

(Figures 1 through 8)

FIGURE 1. Cross Section of the Weld Studied in This Investigation. The area near B showed grain boundary precipitation. The area near A was free of grain boundary particles. 4X

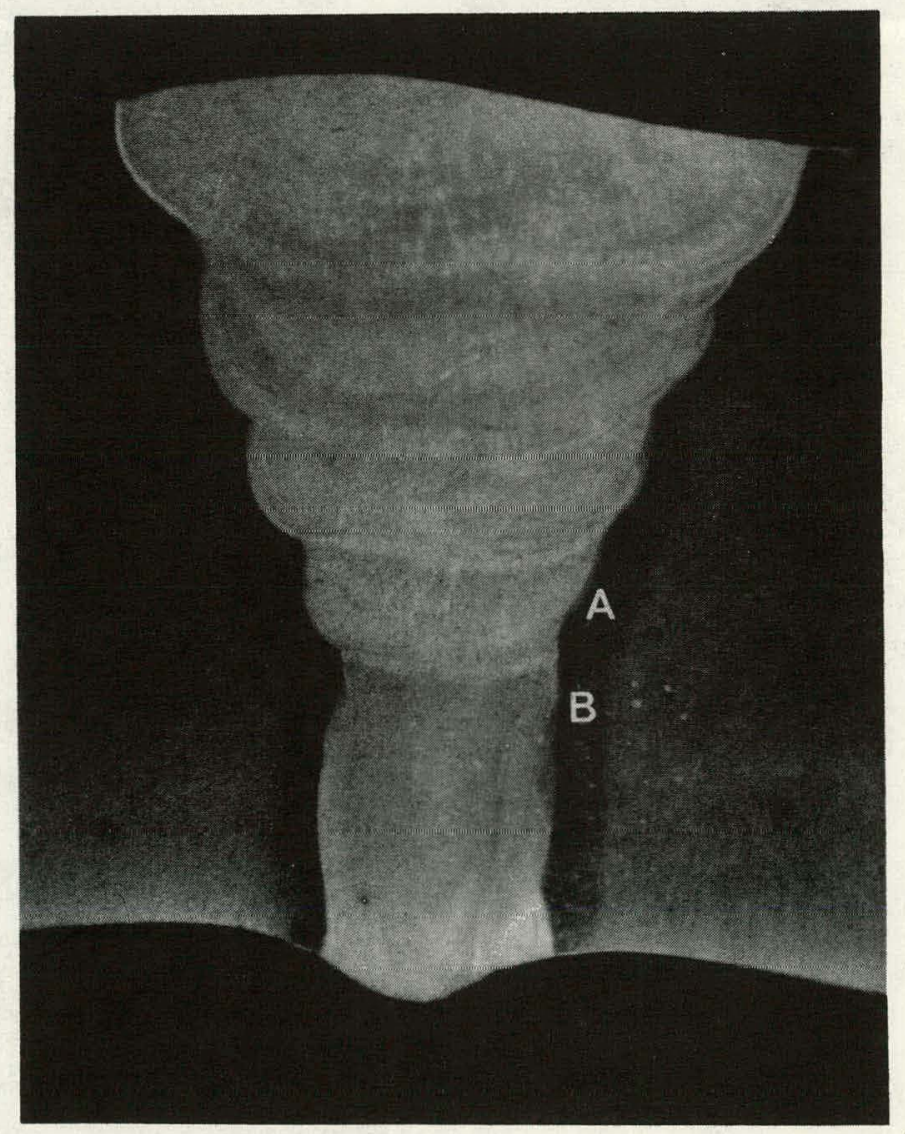




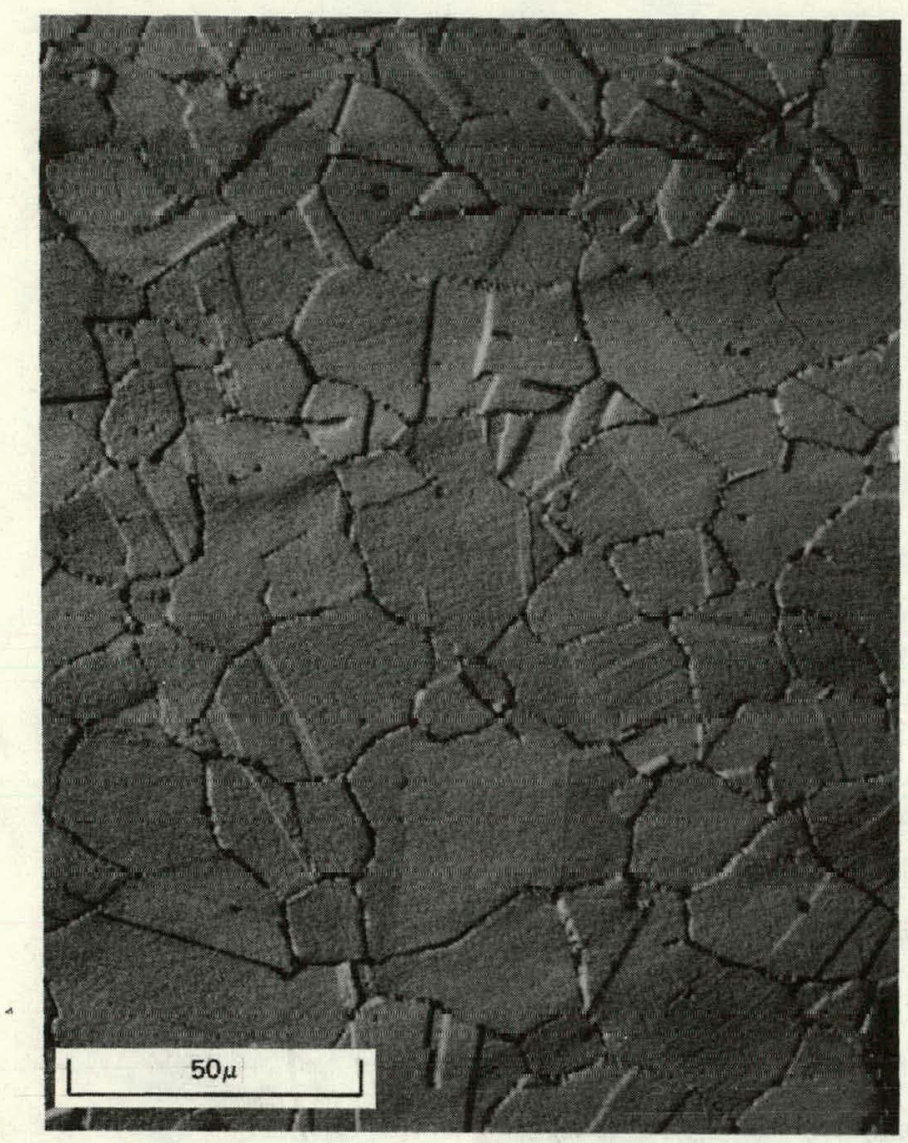

FIGURE 2. Optical Micrograph of Heat Affected Zone Near B in Figure 1 Showing Large Grain Size and Grain Boundary Precipitates. 580X
FIGURE 3. Optical Micrograph of Base Metal Far Removed From the Weld Showing Fine Grain Size and Absence of Grain Boundary Phase. 580X

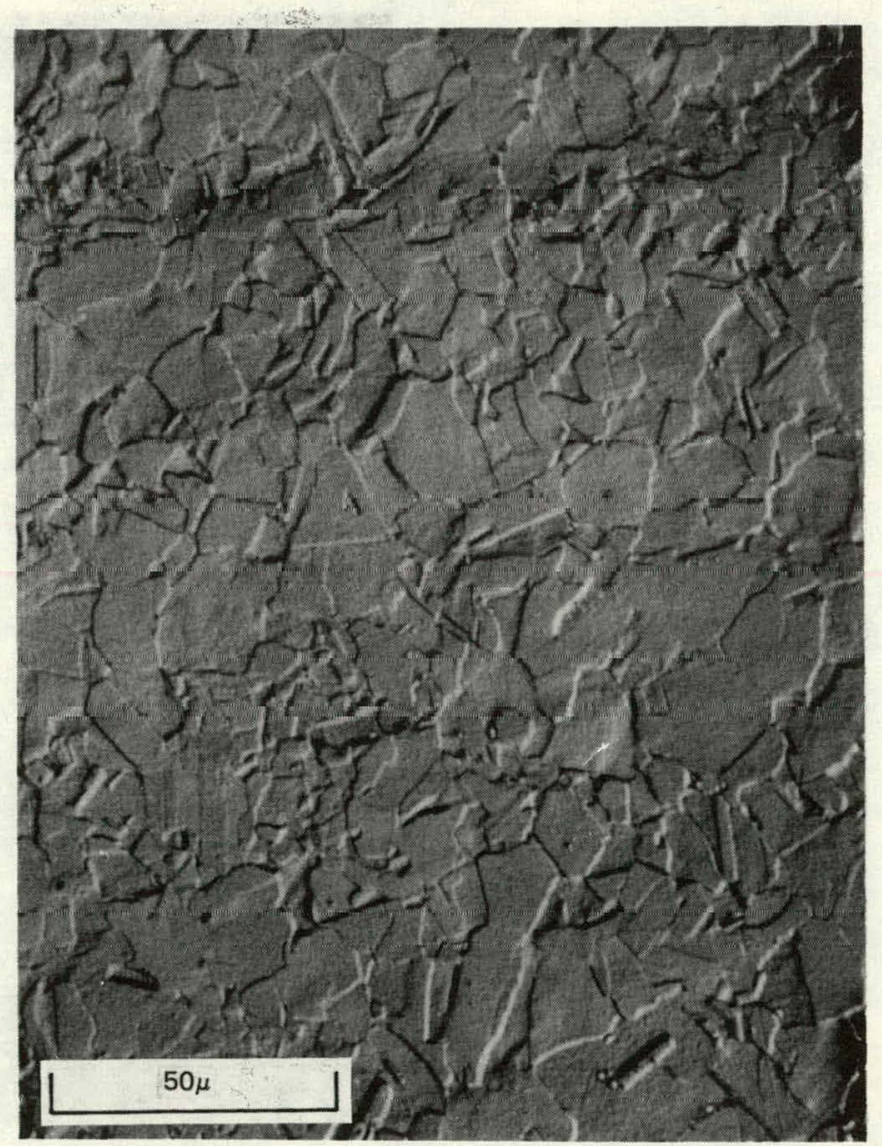


FIGURE 4. Optical Micrograph of the Heat Affected Zone After the Oxalic Etch Test. The ditch structure in the lower portion indicates possible sensitization and is typical of the area near B in Figure 1. The step structure in the upper portion is typical of the area near A in Figure 1 and indicates that no sensitization is present. $400 \mathrm{X}$

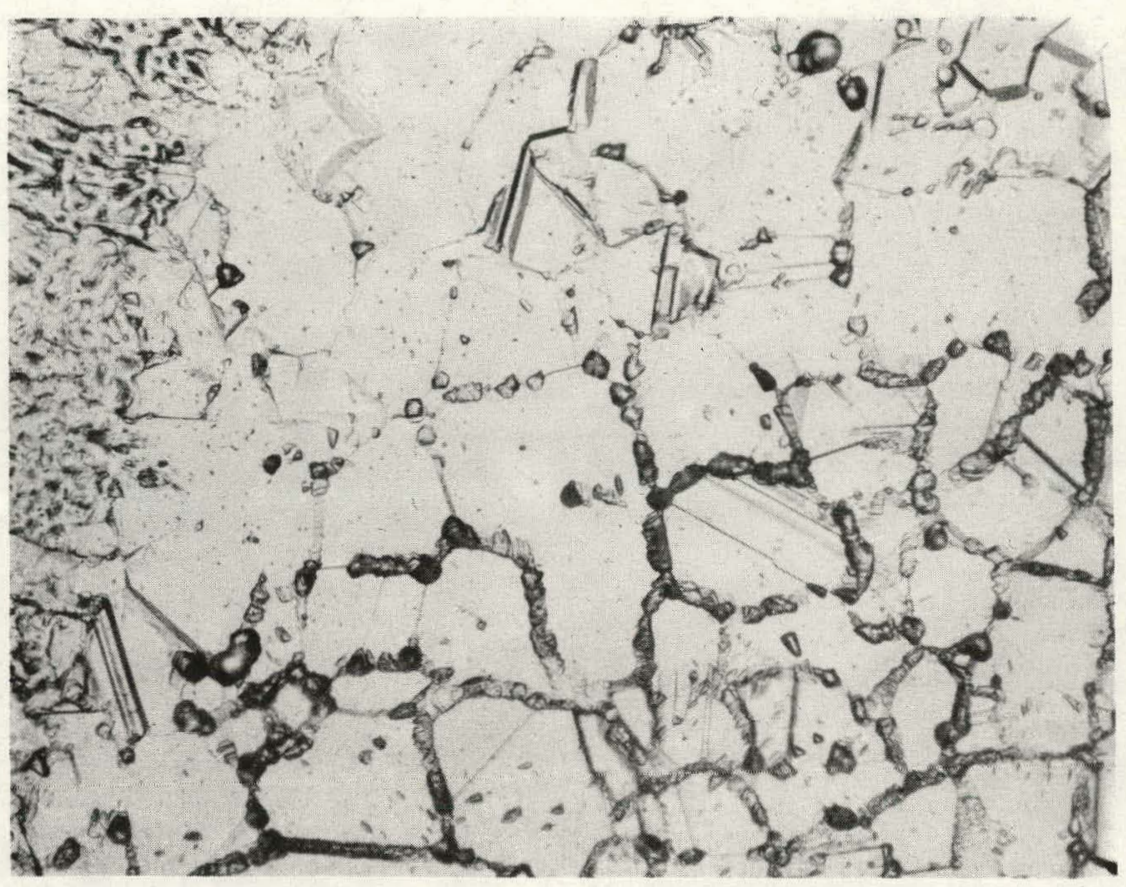


RFP-2837

FIGURE 5. TEM Brightfield Micrograph Showing Three Grain Boundary Precipitates in the Area of B in Figure 1. 75,000X

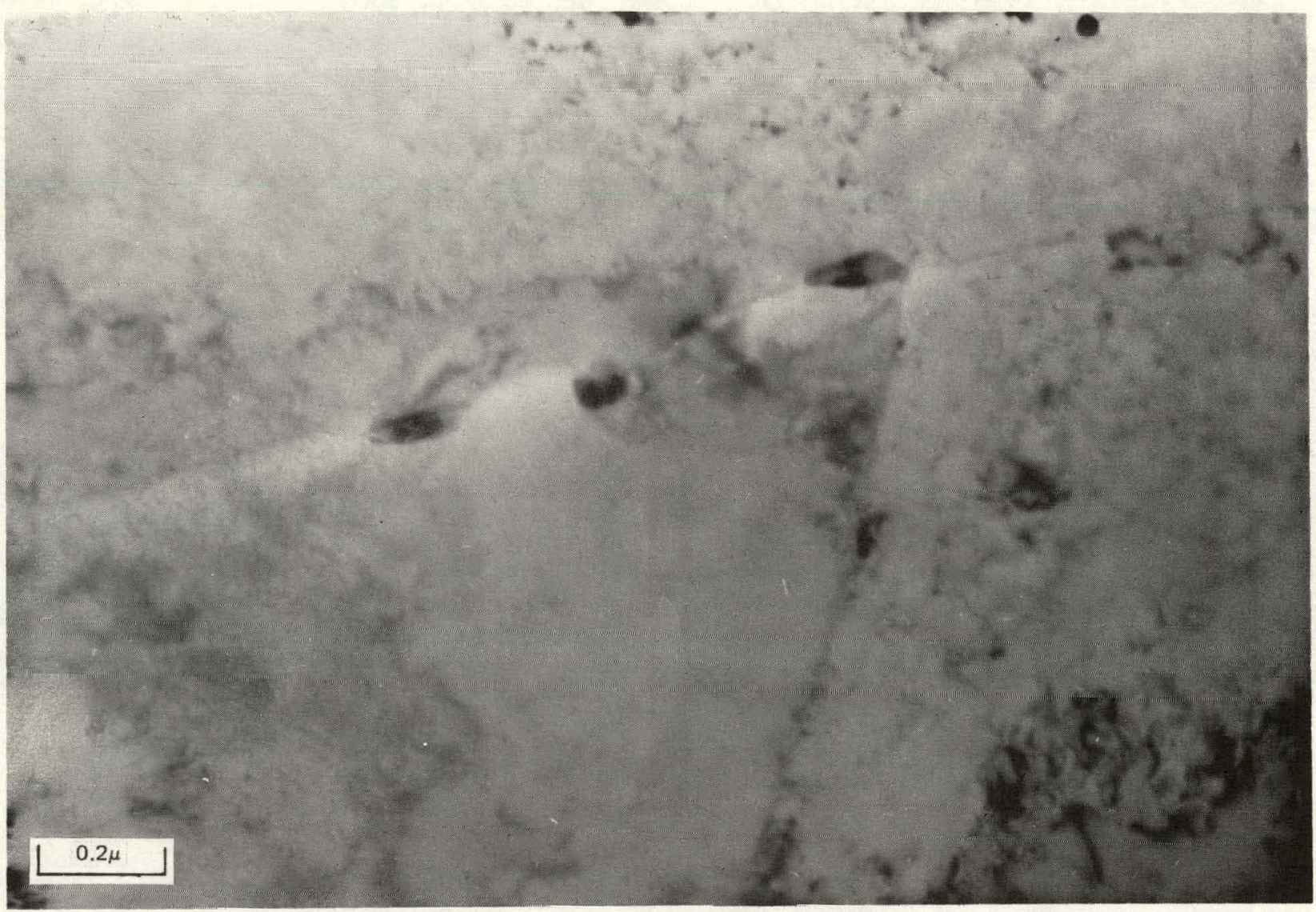


FIGURE 6. Selected Area Diffraction Pattern From the Area of Figure 5. The faint diffraction pattern shown is the $11 \overline{4}$ zone of $\mathrm{M}_{23} \mathrm{C}_{6}$.

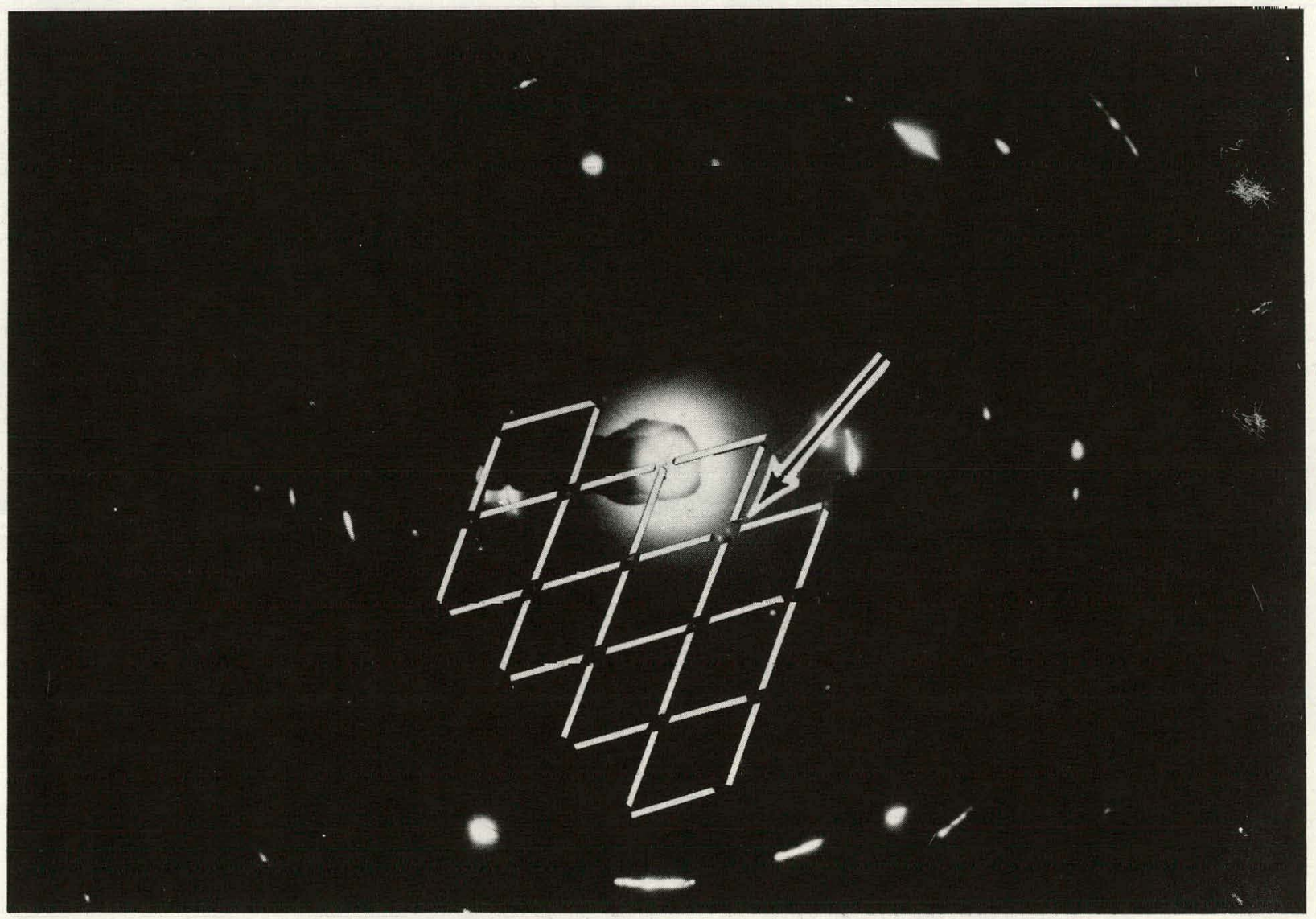




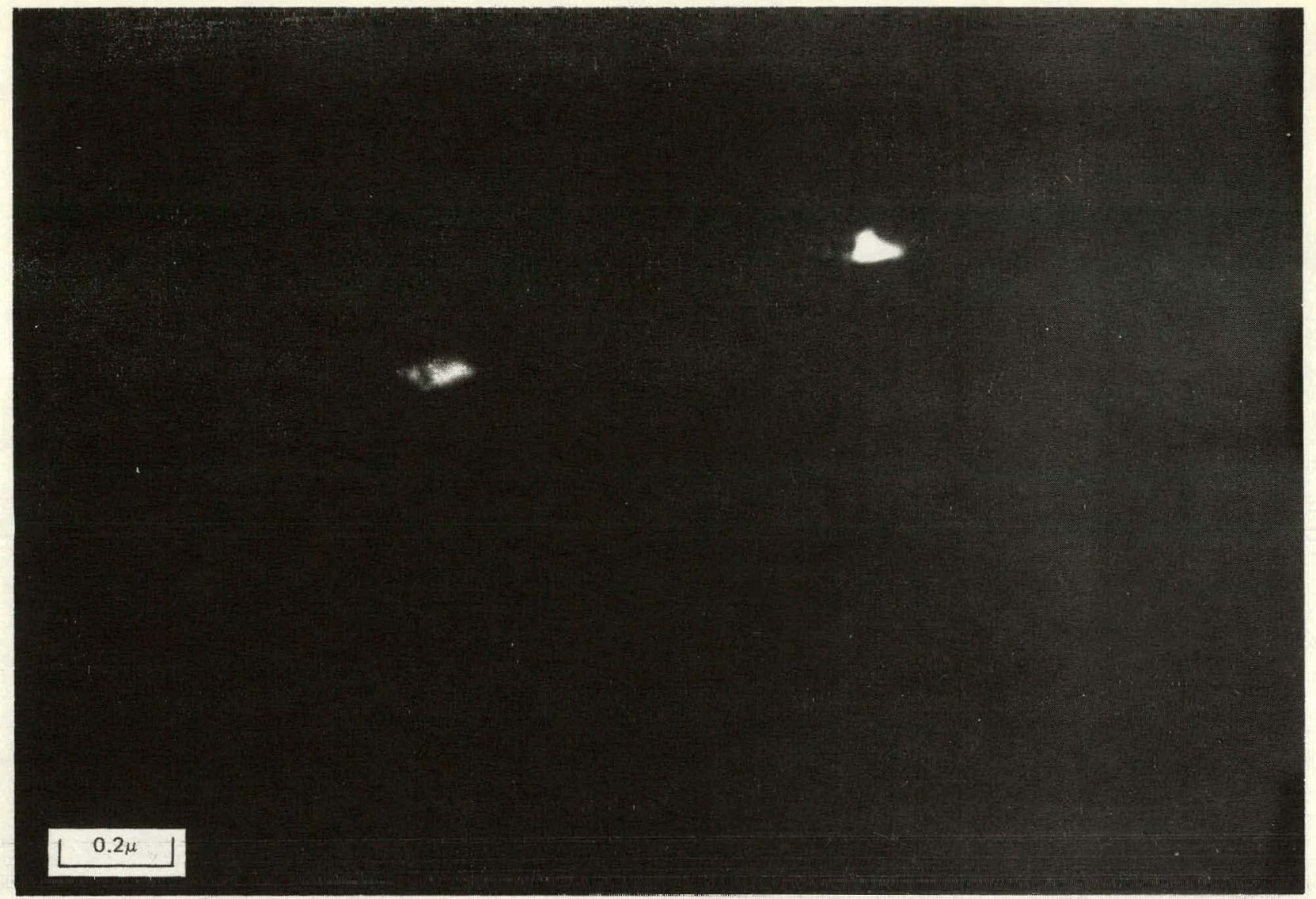

FIGURE 7. TEM Darkfield Image of the Indicated Pair of Spots in Figure 6, Showing That These Particles are the Source of the $\mathrm{M}_{23} \mathrm{C}_{6}$-Type Diffraction Pattern. $75,000 \mathrm{X}$

FIGURE 8. Optical Micrograph Showing Slight Grain Boundary Attack in the Heat Affected Zone as a Result of the Huey Test. 400X

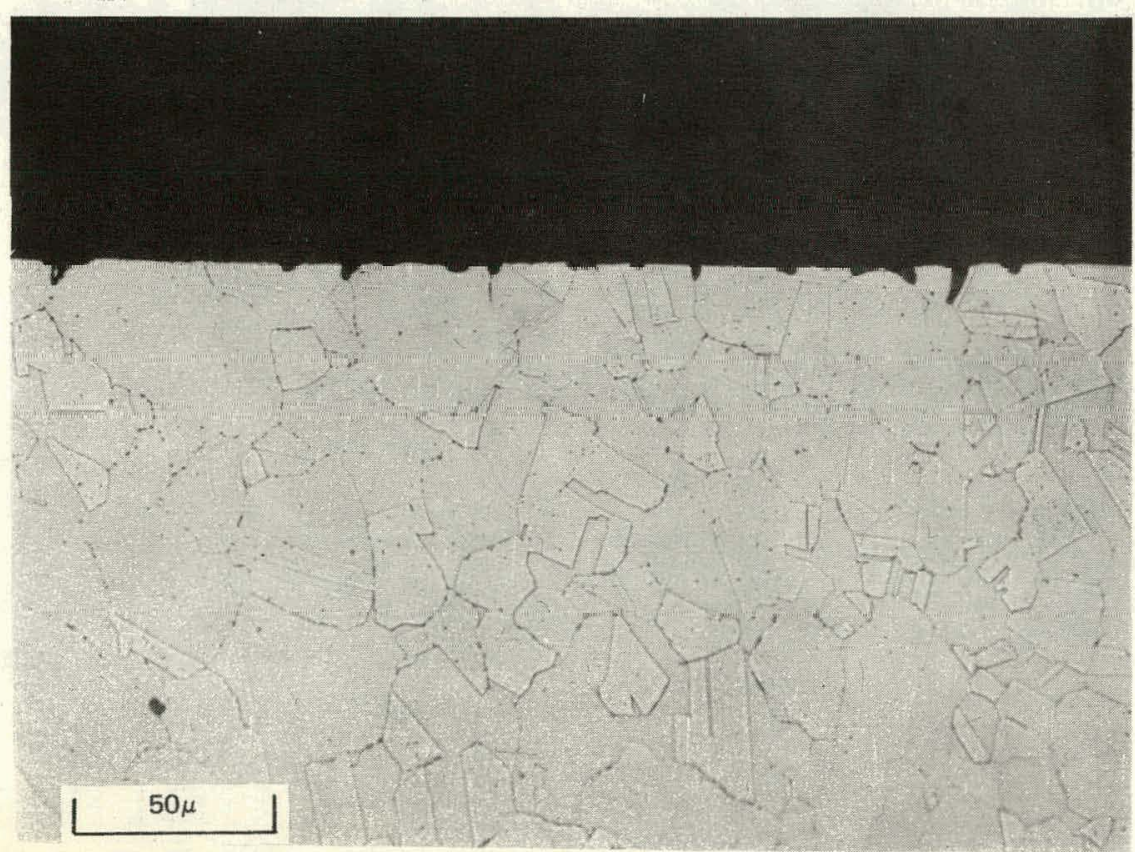

